\title{
Correction to: Provenance- and life-history stage-specific responses of the dwarf shrub Calluna vulgaris to elevated vapour pressure deficit
}

\author{
Karin Ibe $(\mathbb{D} \cdot$ David Walmsley $(\mathbb{D} \cdot$ Andreas Fichtner $(\mathbb{D} \cdot$ Heinz Coners $\mathbb{D}$ - \\ Christoph Leuschner (D) Werner Härdtle $(\mathbb{D}$
}

Published online: 19 October 2021

(C) The Author(s) 2021

\section{Correction to: Plant Ecol (2020) 221:1219-1232 https://doi.org/10.1007/s11258-020-01076-3}

The article "Provenance- and life-history stage-specific responses of the dwarf shrub Calluna vulgaris to elevated vapour pressure deficit", written by "Karin Ibe, David Walmsley, Andreas Fichtner, Heinz Coners, Christoph Leuschner and Werner Härdtle", was originally published Online First without Open Access. After publication in volume 221, issue 12, page 1219-1232 the author decided to opt for Open Choice and to make the article an Open Access publication. Therefore, the copyright of the article has been changed to $($ ) The Author(s) 2021 and the article is forthwith distributed under a Creative Commons Attribution 4.0 International License, which permits use, sharing, adaptation, distribution and reproduction in any medium or format, as long as you give appropriate credit to the original author(s) and the

The original article can be found online at https:// doi.org/10.1007/s11258-020-01076-3.

K. Ibe $(\bowtie) \cdot$ D. Walmsley · A. Fichtner · W. Härdtle Institute of Ecology, Leuphana University of Lüneburg, Universitätsallee 1, 21335 Lüneburg, Germany e-mail: ibe@leuphana.de

H. Coners · C. Leuschner Plant Ecology, Albrecht Von Haller Institute for Plant Sciences, University of Göttingen, Untere Karspüle 2, 37073 Göttingen, Germany source, provide a link to the Creative Commons licence, and indicate if changes were made. The images or other third party material in this article are included in the article's Creative Commons licence, unless indicated otherwise in a credit line to the material. If material is not included in the article's Creative Commons licence and your intended use is not permitted by statutory regulation or exceeds the permitted use, you will need to obtain permission directly from the copyright holder. To view a copy of this licence, visit https://creativecommons.org/ licenses/by/4.0.

The original article has been corrected.

Open Access This article is licensed under a Creative Commons Attribution 4.0 International License, which permits use, sharing, adaptation, distribution and reproduction in any medium or format, as long as you give appropriate credit to the original author(s) and the source, provide a link to the Creative Commons licence, and indicate if changes were made. The images or other third party material in this article are included in the article's Creative Commons licence, unless indicated otherwise in a credit line to the material. If material is not included in the article's Creative Commons licence and your intended use is not permitted by statutory regulation or exceeds the permitted use, you will need to obtain permission directly from the copyright holder. To view a copy of this licence, visit http://creativecommons.org/licenses/by/4.0/.

Publisher's Note Springer Nature remains neutral with regard to jurisdictional claims in published maps and institutional affiliations. 